\title{
General Equilibrium Effects of Trade Liberalization in ECOWAS Countries: Structural Gravity Approach
}

\author{
Mariame Bakouan1, Dorothee Boccanfuso² \\ ${ }^{1}$ Economics and Management Department, University Norbert ZONGO, Koudougou, Burkina Faso \\ ${ }^{2}$ University Mohammed VI Polytechnique, Benguérir, Morocco \\ Email: mariamebakouan@gmail.com, dorothee.BOCCANFUSO@um6p.ma
}

How to cite this paper: Bakouan, M., \& Boccanfuso, D. (2021). General Equilibrium Effects of Trade Liberalization in ECOWAS Countries: Structural Gravity Approach. Modern Economy, 12, 274-292. https://doi.org/10.4236/me.2021.121014

Received: October 13, 2020

Accepted: January 26, 2021

Published: January 29, 2021

Copyright $\odot 2021$ by author(s) and Scientific Research Publishing Inc. This work is licensed under the Creative Commons Attribution International License (CC BY 4.0).

http://creativecommons.org/licenses/by/4.0/ (c) (i) Open Access

\begin{abstract}
This study estimates the general equilibrium effects of the Economic Community of West African States (ECOWAS) free trade agreement, established in 1990, using the structural gravity model. Following the Anderson et al. (2015) methodology, we used country fixed effects as a proxy for multilateral resistance terms, which are considered as general equilibrium trade costs, to estimate the effects of regional trade liberalization on the ECOWAS member countries welfare. This study used data on 45 partners' industrial trade flows from 1980 to 2006 . The results indicate that trade liberalization has had positive effects on ECOWAS members welfare, via consumer or producer welfare channels. The latter channel induces an important change in real GDP relative to the former channel-countries with higher levels of producer welfare than consumer welfare experience greater changes in real GDP.
\end{abstract}

\section{Keywords}

Free Trade, Intra Regional Trade, Structural Gravity Model

\section{Introduction}

The globalization process that began in the 1990s has increased the marginalization risk of the African continent. In 2017, Africa accounted for less than 3\% of global merchandise in value. Compared with other parts of the world, African countries do not trade much with each other. In 2017, the intra-African trade represented only $17 \%$ of African merchandise exports, against $64 \%$ for the Euro Union, 50\% for North America, 48.63\% for Asia, and 20.5\% for South and Central America and the Caribbean. Accordingly, strengthening economic coopera- 
tion among African countries has become a necessity. Indeed, the narrowness of African markets, accompanied by significant trade barriers, tends to make intra-African trade more expensive than Africa's trade with the rest of the world. Thus, the low level of trade is attributable to the non-exploitation of commercial potential. In this context, economic and regional integration through an expansion of the market's size can allow African countries to exploit economies of scale, benefit from technological externalities, and attract a direct foreign investment surplus.

The main objective of regional cooperation is to reduce poverty by intensifying trade and increasing the degree of trade is essential to ending extreme poverty and enhancing shared prosperity. Thus, economic and regional integration is a prerequisite for African countries to benefit from globalization. The African integration process is based on a progressive approach to the activities of the Regional Economic Communities (RECs), which are committed to gradually establishing economic unions in their respective sub-regions. In West Africa, the REC in charge of the integration process is the Economic Community of West African States (ECOWAS). ECOWAS, created on 28th May 1975 , is composed a group of fifteen countries. The creation of a common market is a stated objective in both the ECOWAS and West African Economic and Monetary Union (WAEMU) treaties. An integrated market assumes the free movement of the factors of production and contributes to trade intensification. Accordingly, various reforms have been undertaken to remove trade barriers between members, to increase trade within the region. For instance, a free trade area that eliminates tariffs with the liberalization scheme of trade (SLE) is introduced on 1 January 1990, followed by the adoption of the Common External Tariff (CET) through the establishment of the customs union in January 2015. The underlying objective of the process of economic and regional integration is economic development through trade intensification. In the economic literature, it is generally accepted that Regional Integration by reducing trade barriers contribute to increase trade and, consequently, to economic growth, because of generating efficiency among firms due to competition, increasing employment, and alleviating poverty (Krueger, 1980; Frankel \& Romer, 1999; Dollar, 2002; Dollar \& Kraay, 2004; Dessy et al., 2010; Kamau, 2010; Von Uexkull, 2012; Herzer, 2013; Le Goff \& Singh, 2014; Viet, 2015; Sakyi et al., 2015; Agrawal, 2015; Were, 2015; Zahonogo, 2017; Teignier, 2018). Kamau (2010) believes that trade blocs such as The Common Market for Eastern and Southern Africa (COMESA), the East African Community (EAC), and the Southern African Development Community (SADC), promote growth. In the West Africa context, Von Uexkull (2012) shows that intra-ECOWAS exports contribute to increased productivity, diversification, and job creation. Teignier (2018) shows that changes in productivity and reductions in trade barriers affect sectoral reallocation and, hence, growth and transformation.

Many empirical studies focused on the impact of Sud-Sud trade agreements, 
used the gravity methodology to appreciate the partial effects of these trade agreements. Some works find that these agreements largely affect the trade level, but for others these effects are not significant. These analyses, however, only evaluate the partial impact of regional trade agreements, ignoring the concept of multilateral resistance developed by Anderson \& Van Wincoop (2003). Concealed multilateral resistance, which reflects the effects of third countries, conducts to a specification which suffers from the omitted variable bias.

What are the effects of the trade agreements between African economies on their welfare? In this context of regionalism, it is necessary to evaluate the impact of trade liberalization on welfare. Indeed, the literature establishes a positive impact of trade on income, but trade liberalization reforms are usually implemented to address unemployment in declining sectors. In the extreme poverty context associated with job creation goals, it is unclear how regional trade liberalization reforms affect ECOWAS members' welfare. Our paper objective is to appreciate the effects of ECOWAS's Free trade agreement on the members's welfare. Specifically, it involves analyzing the different channels trough wich trade agreement affects the countries's welfare. The study is an expost analysis of the effects of ECOWAS free trade agreements, captured by a binary variableCEDEAOij, $t$ that equals 1 from 1990. We support that the ECOWAS Free Trade Agreement improved the members welfare. Following the methodology developed by Anderson et al. (2015), Larch \& Yotov (2016) and Yotov et al. (2016), this study aims to estimate the general equilibrium effect of regional trade liberalization on ECOWAS members' welfare using a structural gravity model. As a proxy for the terms of the general equilibrium trade costs, multilateral resistances play an important role in the general equilibrium analysis using the structural gravity model. Many methodologies exist in the literature to capture these terms (Anderson \& Van Wincoop, 2003; Feenstra, 2004; Redding \& Venables, 2004; Straathof et al., 2008; Baier \& Bergstrand, 2009; Behrens et al., 2012; Fally, 2015; Anderson et al., 2015). One of these methods is to use country fixed effects as a proxy (Feenstra, 2004; Redding \& Venables, 2004; Head \& Mayer, 2014; Fally, 2015). Since the fixed effects derived from a structural gravity estimate using the Poisson pseudo maximum likelihood (PPML) are equivalent to the multilateral resistances that corroborate the equation system (Fally, 2015), Anderson et al. (2015), Larch \& Yotov (2016) and Yotov et al. (2016) developed a general equilibrium effects analysis in five steps using the structural gravity model. We used the fast Poisson estimation with the highdimensional fixed effects (PPMLHDFE) estimator developed by Correia et al. (2019) to identify the general equilibrium effects of the ECOWAS free trade agreements on members' welfare. This methodology indicates the general impact of trade policies on trade and other macroeconomic aggregates. Unlike previous works that analysed the effects of the ECOWAS trade liberalization reform using the gravity model, our work analyzes the general equilibrium impact of regional trade liberalization on 
the aggregates of each country member. The remainder of this paper is organized as follows. Section 2 is devoted to studying the analytical framework and describes the data. Section 3 presents the results of the analysis, and Section 4 concludes.

\section{Model and Data}

Since Tinbergen (1962), the gravity equation has been used extensively to analyse trade costs, including the effect of trade agreements. However, most research has focused on the partial effects of trade costs. The use of the structural gravity model to analyse the general equilibrium effects of trade costs was pioneered by Anderson et al. (2015), Larch \& Yotov (2016) and Yotov et al. (2016). Their analysis developed a three-step methodology to study the general equilibrium effects using the structural gravity model.

\subsection{Theoretical Model}

The gravity equation is based on a variety of micro-theoretical foundations. We consider that a world economy is constituted by $n$ countries $i=1, \cdots, n$, each endowed with $q_{i}$ units of a distinct good $i=1, \cdots, n$. Each economy is populated by a representative consumer whose preferences are represented by a Constant Elasticity of Substitution (CES) utility function:

$$
U_{i j}=\left\{\sum_{i}^{n} \Psi_{i j}^{\frac{1-\sigma}{\sigma}} C_{i j}^{\frac{\sigma-1}{\sigma}}\right\}^{\frac{\sigma}{1-\sigma}}
$$

where $C_{i j}$ is the demand for good $i$ in country $j ; \Psi_{i j} \succ 0$ is an exogenous preference parameter; and $\sigma \succ 1$ is the elasticity of substitution between goods from different countries. The associated consumer price index is:

$$
P_{j}=\left(\sum_{i}^{n} \Psi^{1-\sigma} P_{i j}^{1-\sigma}\right)^{\frac{1}{1-\sigma}}
$$

where $P_{i j}$ is the price of good $i$ in country $j$. International trade between economies is subject to trade costs. We maintain iceberg trade costs, which assume that to sell a unit of a good in country $j$, firms from economy $i$ must ship $\tau_{i j} \succ 1$ units, with $\tau_{i i}=1$. The price of good $i$ in country $j$ is equal to $P_{i j}=\tau_{i j} p_{i i}$, where $P_{i i}$ is the domestic price or factory-gate price. Country's $j$ total value imports from country $i$ is denoted by $X_{i j}$. Given CES utility, bilateral trade flows satisfy:

$$
X_{i j}=\left(\frac{\Psi_{i j} p_{i i} \tau_{i j}}{P_{j}}\right)^{1-\sigma} E_{j}
$$

where $E_{j}=\sum_{i}^{n} X_{i j}, X_{i j}$ is country $j$ s total expenditures. The market clearance conditions for goods from each origin enforce the concept that the value of output of country $i\left(Y_{i}\right)$ equals the total expenditures of this economy's variety in all 
global destinations, integrated in country $i$ itself,

$Y_{i}=\sum_{j} X_{i j}=\left(\Psi_{i j} p_{i i}\right)^{1-\sigma} \sum_{j}\left(\frac{\tau_{i j}}{P_{j}}\right)^{1-\sigma} E_{j}$. Supposing world income $Y=\sum_{j} Y_{i}$, we can re-write this equation as follows: $\left(\Psi_{i j} p_{i i}\right)^{1-\sigma}=\frac{\frac{Y_{i}}{Y}}{\Pi_{i}^{1-\sigma}}$. Equation (3) is combined with the $\left(\Psi_{i j} p_{i i}\right)^{1-\sigma}$ expression, $\Pi_{i}^{1-\sigma}$ and the CES prices index, to provide the following structural gravity system:

$$
\begin{gathered}
X_{i j}=\frac{Y_{i} E_{j}}{Y}\left(\frac{\tau_{i j}}{\Pi_{i} P_{j}}\right)^{1-\sigma} \\
\Pi_{i}^{1-\sigma}=\sum_{j}\left(\frac{\tau_{i j}}{P_{j}}\right)^{1-\sigma} \frac{E_{j}}{Y} \\
P_{j}^{1-\sigma}=\sum_{i}\left(\frac{\tau_{i j}}{\Pi_{i}}\right)^{1-\sigma} \frac{Y_{i}}{Y} \\
p_{i}=\left(\frac{Y_{i}}{Y}\right)^{\frac{1}{1-\sigma}} \frac{1}{\alpha_{i} \Pi_{i}} \\
E_{i}=\phi_{i} Y_{i}=\phi_{i} p_{i} q_{i}
\end{gathered}
$$

Equation (4), the theoretical gravity equation, describes trade flows $X_{i j}$ from origin country $i$ to destination country $j$. Following Anderson \& Van Wincoop (2003), Equations (5) and (6) represent the multilateral resistances. $\Pi_{i}$, the outward multilateral resistance, or OMR, and $P_{j}$, the inward multilateral resistance, or IMR, are structural gravity terms that occupied the central place in the general equilibrium analysis. Intuitively, the multilateral resistances imply that, all else equal, two economies will trade more with each other the more remote they are from the rest of the world. In Equations (7) and (8), $p_{i}$ is the factory-gate price for each variety of goods in country of origin $i, E_{i}$ aggregates the expenditures of country $i, q_{i}$ is the supply of each good, and $\phi_{i}$ is an exogenous parameter that establishes the relation between the output value and aggregate expenditures.

\subsubsection{Model Specification}

In the trade literature, trade costs are captured by transportation costs, tariffs, non-tariff barriers, cultural factors, geographical determinants, and institutional factors. Following the international trade literature, trade costs in West Africa can be explained by geographical, cultural, and historical impediments as well as political and economic institutions. Hence, trade costs are explained by the bilateral distance between partners, distij. Contiguity Cont $_{i j}$ equals 1 when partners share the same border, and the landlocked variable $E n c l_{j}$ equals 1 when the importing country is landlocked. We also use the language $\operatorname{Lan}_{i j}$ and common religion ComRel $l_{i j}$ variables to capture cultural proximity, and colonial links $\operatorname{Conl}_{i j}$ as 
a proxy for institutional proximity. Trade agreements from lower trade barriers contribute to promoting trade. We add variables that capture the effects of trade agreements. The difficulty in capturing all of the commercial costs and a lack of data lead us to introduce an error term in our model to capture unobservable and missing data. The multiplicative form of Equation (4) is:

$$
\begin{aligned}
X_{i j, t}= & \exp \left(\Gamma_{i, t}+\Gamma_{j, t}+\beta_{1} \ln \text { Dist }_{i j}+\beta_{2} \text { Cont }_{i j}+\beta_{3} \text { Encl }_{j}+\beta_{4} \text { Lan }_{i j}\right) \\
& * \exp \left(\beta_{5} \text { ComRel }_{i j}+\beta_{6} \text { Conl }_{i j}+\beta_{7} \text { CEDEAO }+\beta_{8} \text { Comcur }_{i j}\right) * \varepsilon_{i j, t}
\end{aligned}
$$

where $\Gamma_{i, t}$ and $\Gamma_{j, t}$ are, respectively, exporter and importer year fixed effects and $\varepsilon_{i j, t}$ is the error term. Following Feenstra (2004), Redding \& Venables (2004), Head \& Mayer (2014) and Anderson et al. (2015), the multilateral resistances are captured by the country fixed effects $\Gamma_{i, t}$ and $\Gamma_{j, t}$. The main goal of our paper is to analyse the effects of the ECOWAS regional free trade agreement established in 1990. In the ECOWAS context, we decompose the interest variable as follows: $C E D E A O_{i j, t}$ takes the value of 1 from 1990 if partners belong to ECOWAS and 0 otherwise, and Comcur ${ }_{i j}$ corresponds to the common currency.

The selection of countries belonging to the trade agreement can induce potential endogeneity (Baier \& Bergstrand, 2007). As recommended by Piermartini \& Yotov (2016), the pair fixed effects $\Psi_{i j}$ can be used to mitigate the potential endogeneity of trade agreements. Integrating pair fixed effects in model (9) also captures all time-invariant trade costs. Hence, equation (10) is expressed as follows:

$$
X_{i j, t}=\exp \left(\Gamma_{i, t}+\Gamma_{j, t}+\Psi_{i j}+\alpha_{1} C E D E A O_{i j, t}\right) * \varepsilon_{i j, t}
$$

\subsubsection{General Equilibrium Estimation Procedure}

Since multilateral resistances are connected to price indices, they are important for analyzing the general equilibrium effects of trade agreements. In the literature, the multilateral resistance terms represent general equilibrium trade cost terms. They imply that trade costs between two partners depend on the bilateral barriers between them relative to the average trade barriers that both countries face with other partners. As described by Anderson et al. (2015), Larch \& Yotov (2016) and Yotov et al. (2016), estimating the general equilibrium effects of trade agreements using the gravity model consists of four essentials steps.

At the first stage, we estimate the econometric gravity specification (9) using the Poisson pseudo-maximum likelihood with high-dimensional fixed effects (PPMLHDFE) estimator developed by Correia et al. (2019). The goal of this step is to obtain the trade costs necessary for a counterfactual analysis. Our sample contains missing trade flow data or zeroes for a given pair. To obtain all estimated fixed effects by the pairs that are necessary to construct bilateral trade costs, we use the two-stage procedure solution developed by Anderson \& Yotov (2016). The estimates of the pairs' fixed effects $\hat{\Psi}_{i j}$, provided by estimating specification (9), are used as the dependent variable in a regression that includes 
standard gravity variables along with importer and exporter fixed effects:

$$
\begin{aligned}
\hat{\tau}_{i j}^{1-\sigma}=\exp \left(\hat{\Psi}_{i j}\right)= & \exp \left(\Gamma_{i, t}+\Gamma_{j, t}+\beta_{1} \ln \operatorname{Dist}_{i j}+\beta_{2} \operatorname{Cont}_{i j}+\beta_{3} \text { Encl }_{j}\right) \\
& * \exp \left(\beta_{4} \operatorname{Lan}_{i j}+\beta_{5} \operatorname{ComRel}_{i j}+\beta_{6} \operatorname{Conl}_{i j}\right) * \varepsilon_{i j, t}
\end{aligned}
$$

The predicted bilateral trade costs $\hat{\tau}_{i j}^{1-\sigma}$ from Equation (11) are used to fill in the missing trade cost values. The full bilateral costs obtained can then be used in a counterfactual analysis. Combined with the data on outputs and expenditures, the estimates' fixed effects from Equation (11) can be used to construct the baseline multilateral resistances. As advocated by Feenstra (2004) and Redding \& Venables (2004), the exports' and imports' fixed effects are used as proxies for the multilateral resistance terms. The $\Gamma_{i}$ exporter fixed effect takes into account the outward multilateral resistances and output, while the $\Gamma_{j}$ importer fixed effect takes into account expenditure and inward multilateral resistances:

$$
\left(\hat{\Pi}_{i, t}^{1-\sigma}\right)^{B}=\frac{Y_{i, t}}{\exp \left(\hat{\Gamma}_{i, t}\right)} E_{0, t}
$$

And

$$
\left(\hat{P}_{j, t}^{1-\sigma}\right)^{B}=\frac{E_{j, t}}{\exp \left(\hat{\Gamma}_{j, t}\right)} \frac{1}{E_{0, t}}
$$

where $Y_{i, t}, E_{j, t}$ and $E_{0, t}$ are the data. The multilateral term $\hat{P}_{0}$ that is removed is normalized $\hat{P}_{0}$ and equals 1 . With $\hat{P}_{0}$, theoretically, the interpretation of $\hat{\Gamma}_{0}$, which is removed, is $E_{0}$.

The following step defines the counterfactual scenario required to simulate the effect of the trade agreement. At this stage, the dummy variable $C E D E A O_{i j, t}$ is re-defined as the ECOWAS free trade agreement were never established by replacing 1 in the first step with 0 . A new trade matrix of counterfactual bilateral trade costs is derived for the counterfactual scenario. The multilateral term of the counterfactual scenario is also derived. The third step of the procedure consists of solving the counterfactual model by constructing the counterfactual indexes of interest in the "conditional" and "full endowment" general equilibrium scenarios after removing $C E D E A O_{i j, t}$. The conditional general equilibrium effects are derived from the following model for 1990:

$$
X_{i j}=\exp \left[\Gamma_{i}^{c}+\Gamma_{j}^{c}+\hat{\tau}_{i j}^{1-\sigma}+\hat{\beta}_{1} C E D E A O_{i j}^{c}\right] * \varepsilon_{i j}^{c}
$$

where CEDEAO $O_{i j}^{c}$ equals 0 for a pair of ECOWAS members as the counterfactual scenario dummy. Equation (14) implies that the ECOWAS free trade agreement was never existed. The fixed effects obtained from Equation (14) are used to recover the conditional multilateral resistance indexes $\left(\hat{\Pi}_{i, t}^{1-\sigma}\right)^{C}$ and $\left(\hat{P}_{j, t}^{1-\sigma}\right)^{C}$, normalized with the reference country. The "full endowment" general equilibrium effect values of the cancellation of $C E D E A O_{i j, t}$ are obtained by implementing a four-stage iterative procedure that allows for endogenous factory gate price, income, expenditure, and trade to adjust to the counterfactual shock. In the last stage, once the "conditional" and "full endowment" general equili- 
brium effects associated with the removal of $C E D E A O_{i j, t}$ have been obtained, the changes expressed in percentages in the different indexes of interest between the baseline scenario and the "conditional" and "full endowment" scenarios can be computed.

\subsection{Data and Sources}

The data used in this analysis span 1980-2006, covering 45 trading partners. Our sample takes into account 9 ECOWAS countries that had data for the analysis period. The endogenous variable is bilateral industrial exports ${ }^{1}$ in thousands of U.S. dollars. The exogenous variables integrate variables that describe the exporter country and the importer country. These variables include bilateral weighted distance, colonial ties, common language, contiguity, a landlocked dummy, and trade agreements decomposed into a common currency and free trade agreements. The bilateral weighted distance, following Head \& Mayer (2002), is based on the bilateral distance between the largest cities of the two countries. These inter-city distances are weighted by the share of the city in the country's overall population. The bilateral trade data and standard gravity variables were obtained from CEPII. ${ }^{2}$

The variable of interest, $C E D E A O_{i j, t,}$ which captures the ECOWAS free trade agreement, is constructed by the authors and equals 0 before 1990 and 1 including and after 1990 (Table 1).

Table 1. Summary statistics.

\begin{tabular}{ccccc}
\hline VARIABLES & Mean & sd & min & $\max$ \\
\hline $\begin{array}{c}\text { Trade Flow } \\
\text { (Thousands US DOLLARS) }\end{array}$ & $2.235 \mathrm{e}+06$ & $5.352 \mathrm{e}+07$ & 0 & $4.136 \mathrm{e}+09$ \\
Distance (pop-wt, km) & 6.864 & 4.103 & 9.560 & 19.476 \\
Contiguity & 0.0340 & 0.181 & 0 & 1 \\
Common official language & 0.199 & 0.399 & 0 & 1 \\
Common colonizer & 0.0855 & 0.280 & 0 & 1 \\
Common currency & 0.0394 & 0.195 & 0 & 0.988 \\
Common religion & 0.182 & 0.232 & 0 & 1 \\
Importer landlocked & 0.203 & 0.402 & 0 & 1 \\
\hline
\end{tabular}

\section{Results and Discussions}

This section presents, first, the gravity model estimate results and, second, the general equilibrium results.

\subsection{Estimation of Baseline Structural Gravity}

We use the PPMLHDFE estimator to estimate the baseline structural gravity model (Equation (9)). Table 2 presents the structural gravity model estimates ${ }^{1}$ International standard industrial classification revision 2.

${ }^{2}$ Centre d'études prospectives et d'informations internationales (CEPII). 
obtained by the ordinary least squares and PPMLHDFE estimators. The results confirm the traditional sign of the gravity variables, except for the signs of the common colonizer and the importer landlocked variables when using the PPMLHDFE estimator. Table 2 shows that regional trade agreements have a positive effect on bilateral trade. Hence, when countries use the same currency, their trade increases by approximately $38 \%((\exp (1.32)-1) \times 100)$. Our variable of interest $C E D E A O_{i j, t}$ which reflects the establishment of the free trade area, has a positive coefficient that is significant at the $1 \%$ level. Therefore, the establishment of the free trade zone in 1990 among the ECOWAS countries contributed to strengthening commercial relations. The free trade agreement contributes to increased ECOWAS intra-trade by $80.22 \%((\exp (0.589)-1) \times 100)$. This free trade agreement the first outcome of a trade liberalization policy also reinforces the cooperation between the two main blocks (French block and English block) of the study region by the market opening.

At this step, our analysis indicates the partial effect of the free trade agreement at the zone level. However, it is inadequate for an appreciation of the effects on each country's welfare. The primary goal of the region's trade liberalization process is to decrease extreme poverty through trade intensification. Hence, it is necessary to identify the general effect of the policy on members' welfare. The general equilibrium estimate permits an analysis of the policy effect by country to identify each country's gain. Multilateral resistance occupies an important place in the general equilibrium analysis and represents the general equilibrium trade costs obtained by selecting a reference country that will not be significantly influenced by counterfactual shocks. Once the explanatory factors of commercial costs are identified, it is possible to construct the cost matrix.

Table 2. Baseline structural gravity estimation.

\begin{tabular}{ccc}
\hline & \multicolumn{2}{c}{ Dependent Variable: Bilateral Trade } \\
\hline VARIABLES & OLS & PPMLHDFE \\
\hline Bilateral distance & $-1.210^{* * *}(0.0476)$ & $-1.107^{* * *}(0.0733)$ \\
Common border & $0.447^{* * *}(0.156)$ & $0.457^{* * *}(0.147)$ \\
Common official language & $0.786^{* * *}(0.0806)$ & $0.282^{* *}(0.116)$ \\
Common colonizer & $0.613^{* * *}(0.114)$ & $-0.299(0.342)$ \\
Common currency & $0.728^{* * *}(0.162)$ & $1.342^{* * *}(0.144)$ \\
Common religion & $0.584^{* * *}(0.105)$ & $1.522^{* * *}(0.227)$ \\
Importer landlocked & $-3.894^{* * *}(0.317)$ & $11.74^{* * *}(0.758)$ \\
CEDEAO & $1.151^{* * *}(0.141)$ & $0.589^{* *}(0.261)$ \\
Observations & 31,974 & 31,116 \\
R-squared & 0.823 & 0.991 \\
Exporter fixed effects & Yes & Yes \\
Importer fixed effects & Yes & Yes \\
\hline
\end{tabular}

Robust standard errors in parentheses. ${ }^{* * *} p<0.01,{ }^{* *} p<0.05,{ }^{*} p<0.1$. 


\subsection{Conditional General Equilibrium of ECOWAS Free Trade Agreement}

To perform our analysis, we choose South Africa as the reference country. Hence, the welfare of the ECOWAS countries is compared to that of the South African consumer and producer welfare. We focus our interpretations on welfare of ECOWAS members.

Table 3 and Table $4^{3}$ present the general equilibrium results. The second and third columns, respectively, expose the conditional and "full endowment" general equilibrium indexes. The Conditional general equilibrium represents the first-order general equilibrium effects of trade liberalization on members countries materialize trough the inward multilateral resistances and the outward multilateral resistances. It quantifies the changes in the direct and indirect trade costs through the inward and outward multilateral resistances, holding expenditures and sales constant. As reported in (column (1) and Figure 1, under the conditional general equilibrium, our results suggest that all the members of ECOWAS experience the increase in the exports. However, there is a substantial heterogeneity, ranging from $1.43 \%$ to $132.74 \%$. The free trade agreement induced the largest increase in intra-ECOWAS exports for countries like Togo (132.74\%), $81.01 \%$ for Burkina-Faso and $72.32 \%$ for Mali. Niger and Ghana experience the smallest increase in exports of approximately $4.13 \%$ and $1.43 \%$, respectively. The main economies in this region (Ivory-Cost and Nigeria) obtained relatively the same growth in exports ( $8.87 \%$ and $8.57 \%$, respectively). The trade liberalization by reducing trade barriers promote trade between the members countries of ECOWAS. The part of the increase in the trade the liberalizing economies is explained by the trade diversion. The results show that the ECOWAS'Free trade agreement effects on the non-members is negligible at less than $1 \%$ but negative, except for the Cameroon. Non-member countries experiencing the largest decrease in exports appear to be countries with high trade ties (Gabon $(-0.20 \%)$; United-Kingdom $(-0.18 \%)$; Indonesia $(-0.08 \%)$ and France $(-0.05 \%))$. However, the result also reveals that the trade agreement impact on some non-members is positive (Cameroon $(0.13 \%)$ and Italia (0.02\%)). Cameroon shares a common border with Nigeria, but there exist the tensions between the countries which tend to limit trade and increase trade costs. Italy has a weak trade ties with the members countries of ECOWAS. Hence, the trade diversion associated the free trade agreement affect positively these countries because they trade very little with these countries.

\subsection{Full General Equilibrium of ECOWAS Free Trade Agreement Effects}

The "full endowment" general equilibrium considers all trade cost changes as well as changes in expenditures and sales resulting from the suppression of tariffs between ECOWAS' members. As highlighted in column (5) of Table 3, the 
values of the "full endowment" general equilibrium effects of ECOWAS' Free trade agreement on exports are qualitatively identical to the corresponding "conditional" equilibrium effects, even though there are a number of quantitative differences.

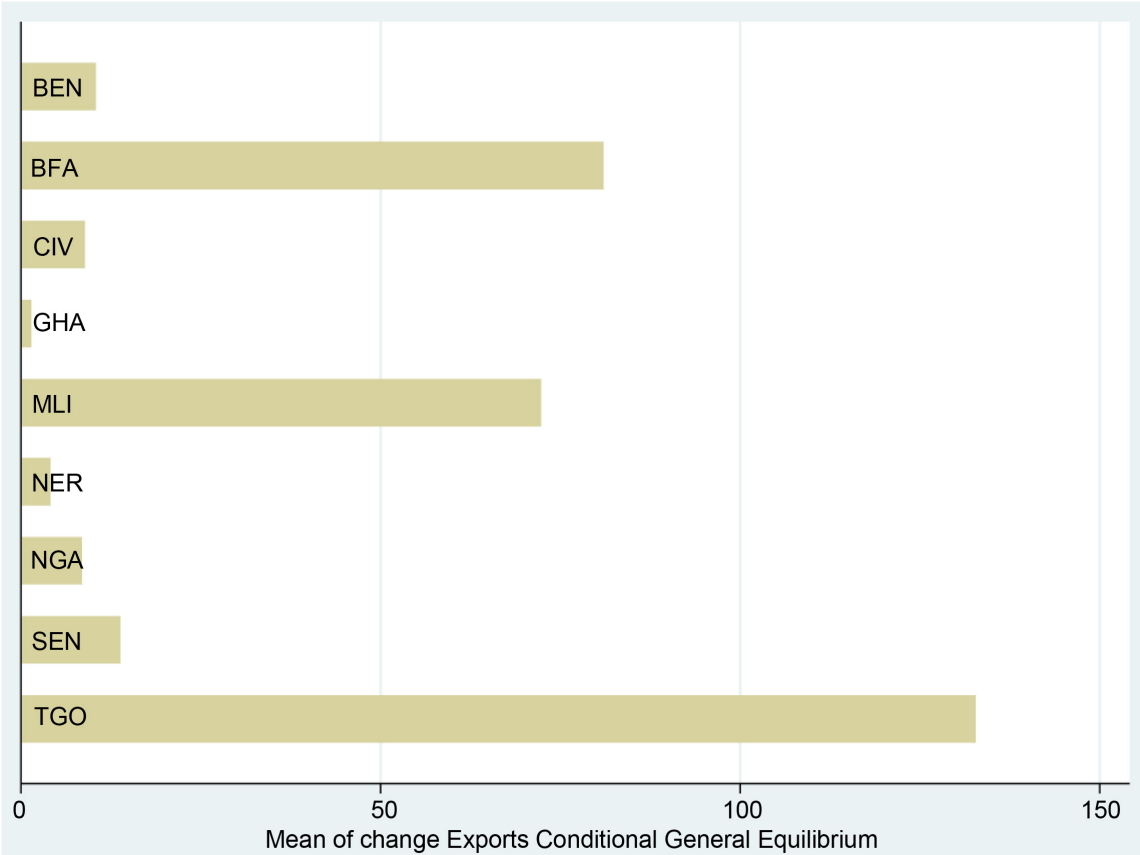

Figure 1. Conditional general equilibrium exports.

Welfare is measured in terms of the percentage change in the real gross domestic product. The results show that deleting tariffs between the ECOWAS members leads to welfare changes ranging from $0.014 \%$ for Burkina-Faso to $3.8 \%$ for Niger. We notice in Figure 2 that five countries recorded a significant increase in welfare from important changes in the real GDP. The country with the highest welfare gain is Niger, which experienced a $3.84 \%$ increase in its real GDP, followed by Benin with a $2.38 \%$ increase in real GDP, Ghana with $2.13 \%$, Senegal with $1.51 \%$, and the Côte-d'Ivoire with $1.19 \%$. The countries with high trade dependency and higher initial tariffs experienced larger welfare gains than those that are less dependent on the region for trade. Niger is a landlocked country with high commercial barriers, similar to other landlocked countries in the region (Burkina-Faso and Mali). Members who only experienced a small increase in welfare are Burkina-Faso with $0.014 \%$, followed by Togo with $0.023 \%$.

The free trade agreement induced the decrease in the inward multilateral resistances in all the members countries, except Côte d'Ivoire (Figure 3). Hence, consumers in these countries face positive effects of the agreement with lower inwards multilateral resistances which improve consumer welfare. Trade liberalization enhances consumer welfare because consumers will have opportunities to choose from a wide variety of better quality and cheaper imports. Countries which experience the largest inwards multilateral resistances decrease are: Mali 


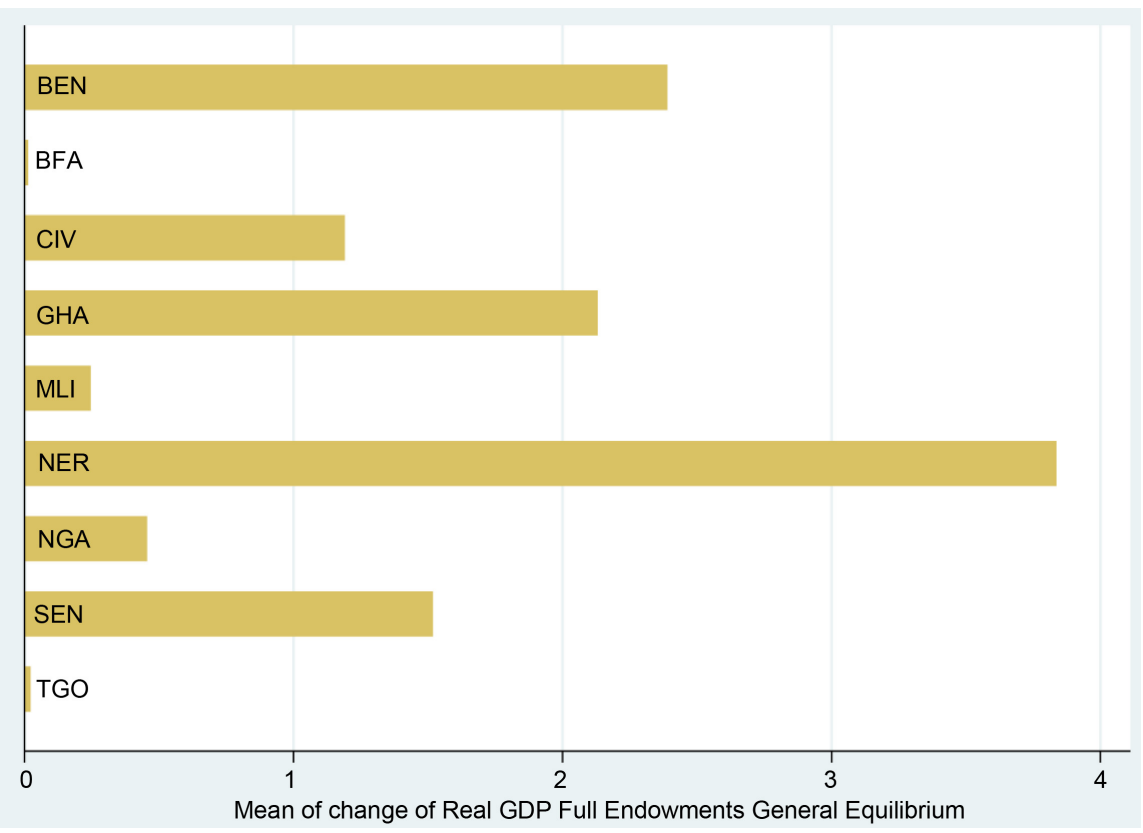

Figure 2. Full endowments general equilibrium real GDP.

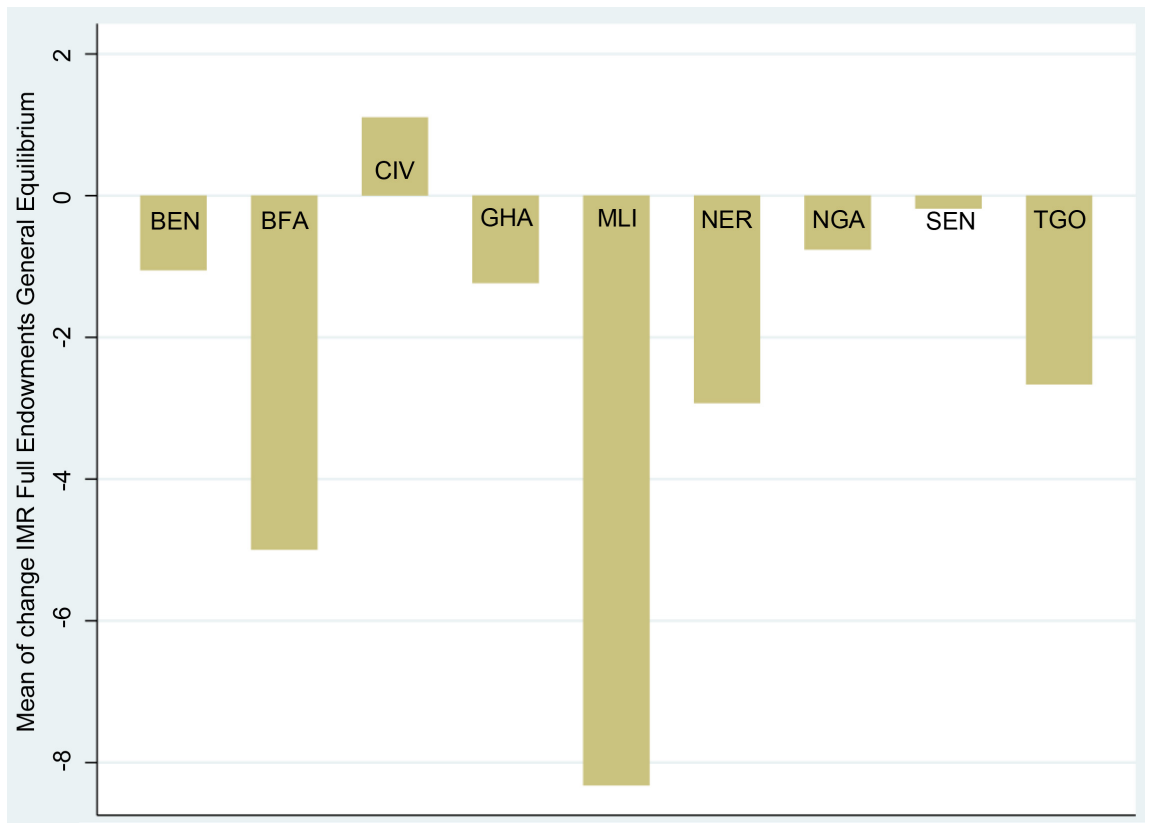

Figure 3. Full endowments general equilibrium IMR.

(-8.32\%); follows by Burkina-Faso (-4.99\%); Niger (-2.93\%) and Togo $(-2.66 \%)$. However, the graph (3) suggests that Côte d'Ivoire consumers welfare was deteriorated because the free trade agreement induced the increase in the inwards multilateral resistances.

In the "full endowment" general equilibrium scenario, falling in the Outward Multilateral Resistances (OMRs) and increasing producer prices also induced gains for all producers. Producer welfare is captured by the percentage change differences between the full OMRs, the baseline OMRs, and the factory-gate 
price. The producer gain corresponds to lower OMRs which translate into higher factory-gate prices (columns (8) and (9)). Figure 4 shows that falling in the OMRs associated the increase in the factory-gate prices is noticed in five countries: Benin with a $-1.50 \%$ fall in OMRs and a producer price gain of $1.29 \%$, Côte d'Ivoire with a $-2.62 \%$ fall in OMRs and a producer price gain of $2.26 \%$, Ghana with a $-1.00 \%$ fall in OMRs and a producer price gain of $0.86 \%$, Niger with a $-0.92 \%$ fall in OMRs and a producer price gain of $0.92 \%$, and Senegal with a $-1.53 \%$ fall in OMRs and a producer price gain of $1.31 \%$. We noticed the increase in the outward multilateral resistances translate into the factory-gate price decrease in countries like Mali (10.35\% and $-8.81 \%)$; Burkina-Faso (6.15\% and $-5.24 \%)$ and Nigeria $(0.36 \%$ and $-0.31 \%)$.

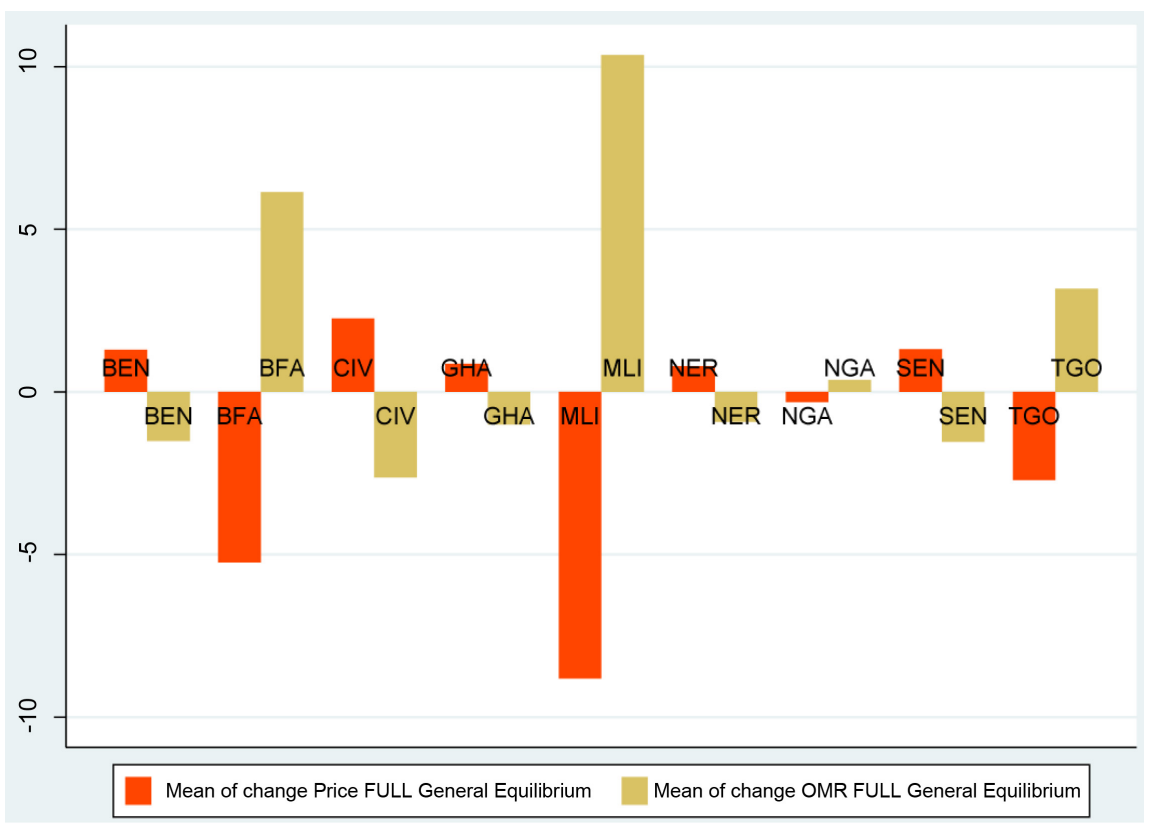

Figure 4. Full endowments general equilibrium OMR and price.

\section{Conclusion}

Our study analysed the general equilibrium effects of the ECOWAS Free Agreement Trade established in 1990, using the General Equilibrium Gravity Analysis with the Poisson Pseudo Maximum Likelihood Procedure. The multilateral resistance term of Anderson \& Van Wincoop (2003) represents general equilibrium trade cost terms by capturing changes in bilateral trade costs. This approach allowed us to use a gravity model to estimate not only the partial effect of the free trade agreement but also to appreciate its effects on member welfare using bilateral industrial trade flow data from 45 countries for 1980-2006. In aggregate, our results confirm the positive effects of the free trade agreement on members' trade and welfare. The welfare decomposition allowed us to appreciate the liberalization effects on consumer and producer welfare. Our analysis identifies two groups of countries by considering the free trade agreements effects: countries in which the gains are mostly on the consumer side (Burkina-Faso, Mali, Togo, and 
Nigeria) and countries in which the gains are mostly on the producer side (Benin, Côte d'Ivoire, Ghana, Niger, and Senegal). The first group the producer welfare decreases means that the trade barriers reducing facilitated access to the market of those countries making their producers less competitive because of the weak industrial sector. The trade agreement effect on their welfare is less than countries which realized the increase in the producer welfare. We note that the effects of the trade agreement on real GDP are pronounced in countries with elevated producer welfare. These countries, except for Niger, have developed industrial sectors. Hence, trade liberalization allows firms in these countries to access the market of others countries without being forced to set up operations in each country. In this context, trade liberalization will lead to activity agglomeration in these countries and will increase the inequality related to development. Our result supports the concept that the industrialization process based on countries' potential must occupy an important place in regional integration policy.

The present analysis is focused on the static effects of the free trade agreement of ECOWAS on the member countries. Future analyses can introduce dynamics in the sectoral gravity model or appreciate the effects of tariffs reducing on the sectoral trade.

\section{Conflicts of Interest}

The authors declare no conflicts of interest regarding the publication of this paper.

\section{References}

Agrawal, P. (2015). The Role of Exports in India's Economic Growth. The Journal of International Trade \& Economic Development, 24, 835-859.

https://doi.org/10.1080/09638199.2014.968192

Anderson, J. E., \& Van Wincoop, E. (2003). Gravity with Gravitas: A Solution to the Border Puzzle. The American Economic Review, 93, 170-192.

https://doi.org/10.1257/000282803321455214

Anderson, J. E., \& Yotov, Y. V. (2016). Terms of Trade and Global Efficiency Effects of Free Trade Agreements, 1990-2002. Journal of International Economics, 99, 279-298. https://doi.org/10.1016/j.jinteco.2015.10.006

Anderson, J. E., Larch, M., \& Yotov, Y. (2015). Estimating General Equilibrium Trade Policy Effects: GE PPML. World Economy, 41, 2750-2782.

Baier, S. L., \& Bergstrand, J. H. (2007). Do Free Trade Agreements Actually Increase Members' International Trade? Journal of International Economics, 71, 72-95. https://doi.org/10.1016/j.jinteco.2006.02.005

Baier, S. L., \& Bergstrand, J. H. (2009). Estimating the Effects of Free Trade Agreements on International Trade Flows Using Matching Econometrics. Journal of International Economics, 77, 63-76. https://doi.org/10.1016/j.jinteco.2008.09.006

Behrens, K., Ertur, C., \& Koch, W. (2012). “Dual” Gravity: Using Spatial Econometrics to Control for Multilateral Resistance. Journal of Applied Econometrics, 27, 773-794.

https://doi.org/10.1002/jae.1231 
Correia, S., Guimarães, P., \& Zylkin, T. (2019). Ppmlhdfe: Fast Poisson Estimation with High-Dimensional Fixed Effects.

Dessy, S., Mbiekop, F., \& Pallage, S. (2010). On the Mechanics of Trade-Induced Structural Transformation. Journal of Macroeconomics, 32, 251-264. https://doi.org/10.1016/j.jmacro.2009.10.003

Dollar, D. (2002). Growth Is Good for the Poor. Journal of Economic Growth, 7, 195-225. https://doi.org/10.1023/A:1020139631000

Dollar, D., \& Kraay, A. (2004). Trade, Growth, and Poverty. The Economic Journal, 114, F22-F49. https://doi.org/10.1111/j.0013-0133.2004.00186.x

Fally, T. (2015). Structural Gravity and Fixed Effects. Journal of International Economics, 97, 76-85. https://doi.org/10.1016/j.jinteco.2015.05.005

Feenstra, R. C. (2004). Advanced International Trade: Theory and Evidence. Princeton, NJ: Princeton University Press.

Frankel, J. A., \& Romer, D. (1999). Does Trade Cause Growth? The American Economic Review, 89, 379-399. https://doi.org/10.1257/aer.89.3.379

Head, K., \& Mayer, T. (2002). Illusory Border Effects: Distance Mis-Measurement Inflates Estimates of Home Bias in Trade (Volume 1).

Head, K., \& Mayer, T. (2014). Gravity Equations: Workhorse, Toolkit, and Cookbook. In Handbook of International Economics (Volume 4, pp. 131-195). Amsterdam: Elsevier. https://doi.org/10.1016/B978-0-444-54314-1.00003-3

Herzer, D. (2013). Cross-Country Heterogeneity and the Trade-Income Relationship. World Development, 44, 194-211. https://doi.org/10.1016/j.worlddev.2012.09.014

Kamau, N. L. (2010). The Impact of Regional Integration on Economic Growth: Empirical Evidence from COMESA, EAC and SADC Trade Blocs. American Journal of Social and Management Sciences, 1, 150-163. https://doi.org/10.5251/ajsms.2010.1.2.150.163

Krueger, B. A. (1980). Trade Policy as an Input to Development. The American Economic Review, 70, 288-292. https://doi.org/10.3386/w0466

Larch, M., \& Yotov, Y. (2016). General Equilibrium Trade Policy Analysis with Structural Gravity.

Le Goff, M., \& Singh, R. J. (2014). Does Trade Reduce Poverty? A View from Africa. Journal of African Trade, 1, 5-14. https://doi.org/10.1016/j.joat.2014.06.001

Piermartini, R., \& Yotov, Y. (2016). Estimating Trade Policy Effects with Structural Gravity.

Redding, S., \& Venables, A. J. (2004). Economic Geography and International Inequality. Journal of International Economics, 62, 53-82.

https://doi.org/10.1016/j.jinteco.2003.07.001

Sakyi, D., Villaverde, J., \& Maza, A. (2015). Trade Openness, Income Levels, and Economic Growth: The Case of Developing Countries, 1970-2009. The Journal of International Trade \& Economic Development, 24, 860-882.

https://doi.org/10.1080/09638199.2014.971422

Straathof, B., Linders, G. J., Lejour, A., Jan, M. et al. (2008). The Internal Market and the Dutch Economy: Implications for Trade and Economic Growth. Technical Report, CPB Netherlands Bureau for Economic Policy Analysis.

Teignier, M. (2018). The Role of Trade in Structural Transformation. Journal of Development Economics, 130, 45-65. https://doi.org/10.1016/j.jdeveco.2017.09.002

Tinbergen, J. (1962). An Analysis of World Trade Flows. Shaping the World Economy, 3, 1-117. https://doi.org/10.1002/tie.5060050113 
Viet, N. C. (2015). The Impact of Trade Facilitation on Poverty and Inequality: Evidence from Low- and Middle-Income Countries. The Journal of International Trade \& Economic Development, 24, 315-340. https://doi.org/10.1080/09638199.2014.898315

Von Uexkull, E. (2012). Regional Trade and Employment in ECOWAS. In D. Lippoldt (Ed.), Policy Priorities for International Trade and Jobs (p. 415). Paris: OECD.

Were, M. (2015). Differential Effects of Trade on Economic Growth and Investment: A Cross-Country Empirical Investigation. Journal of African Trade, 2, 71-85. https://doi.org/10.1016/j.joat.2015.08.002

Yotov, Y. V., Piermartini, R., Monteiro, J.-A., \& Larch, M. (2016). An Advanced Guide to Trade Policy Analysis: The Structural Gravity Model. Geneva: World Trade Organization. https://doi.org/10.30875/abc0167e-en

Zahonogo, P. (2017). Trade and Economic Growth in Developing Countries: Evidence from Sub-Saharan Africa. Journal of African Trade, 3, 41-56. 


\section{Appendix}

Table 3. ECOWAS's free trade agreements effects.

\begin{tabular}{|c|c|c|c|c|c|c|c|c|c|}
\hline & \multicolumn{5}{|c|}{ Conditional GE } & \multicolumn{4}{|c|}{ Full Endowments GE } \\
\hline & (1) & (2) & (3) & $(4)$ & (5) & (6) & (7) & (8) & (9) \\
\hline Country & $\begin{array}{c}\text { Exports } \\
(\%)\end{array}$ & $\begin{array}{c}\text { RGDP } \\
(\%)\end{array}$ & IMRs (\%) & $\begin{array}{c}\text { OMRs } \\
(\%)\end{array}$ & Exports (\%) & RGDP (\%) & IMRs (\%) & $\begin{array}{c}\text { OMRs } \\
(\%)\end{array}$ & Price \\
\hline ARG & -0.01 & 0.01 & -0.01 & 0.00 & $4.14 \mathrm{E}+09$ & 0.00 & -0.00 & 0.00 & -0.00 \\
\hline AUS & -0.04 & -0.00 & 0.00 & -0.00 & $4.14 \mathrm{E}+09$ & 0.00 & 0.00 & -0.01 & 0.01 \\
\hline AUT & -0.00 & -0.00 & 0.00 & -0.00 & $4.14 \mathrm{E}+09$ & 0.00 & 0.00 & -0.00 & 0.00 \\
\hline BEN & 10.41 & 1.06 & -1.05 & -1.30 & $4.56 \mathrm{E}+09$ & 2.39 & -1.05 & -1.52 & 1.29 \\
\hline BFA & 81.01 & 5.26 & -5.00 & 5.25 & $7.49 \mathrm{E}+09$ & 0.01 & -4.99 & 6.15 & -5.24 \\
\hline BOL & -0.99 & 0.12 & -0.13 & 0.39 & $4.08 \mathrm{E}+09$ & -0.27 & -0.13 & 0.46 & -0.39 \\
\hline BRA & -0.02 & 0.00 & -0.01 & 0.00 & $4.14 \mathrm{E}+09$ & 0.00 & -0.01 & 0.00 & -0.00 \\
\hline CAN & -0.00 & 0.00 & -0.00 & -0.00 & $4.14 \mathrm{E}+09$ & 0.00 & -0.00 & -0.00 & 0.00 \\
\hline CHE & -0.00 & -0.00 & 0.00 & -0.00 & $4.14 \mathrm{E}+09$ & 0.00 & 0.00 & -0.00 & 0.00 \\
\hline $\mathrm{CHN}$ & -0.01 & 0.00 & -0.00 & 0.00 & $4.14 \mathrm{E}+09$ & 0.00 & -0.00 & 0.00 & -0.00 \\
\hline CIV & 8.87 & -1.09 & 1.10 & -2.26 & $4.50 \mathrm{E}+09$ & 1.19 & 1.10 & -2.63 & 2.26 \\
\hline CMR & 0.13 & 0.07 & -0.07 & 0.05 & $4.15 \mathrm{E}+09$ & 0.01 & -0.07 & 0.06 & -0.05 \\
\hline $\mathrm{COL}$ & 0.00 & 0.00 & -0.00 & 0.00 & $4.14 \mathrm{E}+09$ & 0.00 & -0.00 & 0.00 & -0.00 \\
\hline DEU & -0.00 & -0.00 & 0.00 & -0.00 & $4.14 \mathrm{E}+09$ & 0.00 & -0.00 & -0.00 & 0.00 \\
\hline DNK & -0.01 & -0.00 & 0.00 & -0.00 & $4.14 \mathrm{E}+09$ & 0.00 & 0.00 & -0.00 & 0.00 \\
\hline DZA & -0.00 & -0.00 & 0.00 & -0.00 & $4.14 \mathrm{E}+09$ & 0.00 & 0.00 & -0.00 & 0.00 \\
\hline EGY & -0.02 & 0.00 & -0.00 & -0.00 & $4.14 \mathrm{E}+09$ & 0.00 & 0.00 & -0.00 & 0.00 \\
\hline ESP & -0.02 & -0.00 & 0.00 & -0.00 & $4.14 \mathrm{E}+09$ & 0.00 & -0.00 & -0.01 & 0.01 \\
\hline FIN & -0.00 & -0.00 & 0.00 & -0.00 & $4.14 \mathrm{E}+09$ & 0.00 & 0.00 & -0.00 & 0.00 \\
\hline FRA & -0.05 & -0.01 & 0.00 & -0.00 & $4.14 \mathrm{E}+09$ & -0.00 & 0.00 & -0.01 & 0.01 \\
\hline GAB & -0.20 & -0.11 & 0.12 & 0.01 & $4.14 \mathrm{E}+09$ & -0.12 & 0.11 & 0.01 & -0.01 \\
\hline GBR & -0.18 & 0.00 & -0.00 & -0.00 & $4.14 \mathrm{E}+09$ & 0.00 & -0.00 & -0.00 & 0.00 \\
\hline GHA & 1.43 & 1.25 & -1.24 & 0.86 & $4.20 \mathrm{E}+09$ & 2.13 & -1.24 & -1.00 & 0.86 \\
\hline IDN & -0.01 & 0.00 & -0.00 & 0.00 & $4.14 \mathrm{E}+09$ & 0.00 & -0.00 & 0.00 & -0.00 \\
\hline IND & -0.08 & 0.00 & -0.00 & 0.00 & $4.14 \mathrm{E}+09$ & 0.00 & -0.00 & 0.00 & -0.00 \\
\hline ITA & 0.02 & -0.00 & 0.00 & -0.00 & $4.14 \mathrm{E}+09$ & 0.00 & 0.00 & -0.01 & 0.01 \\
\hline JPN & -0.00 & 0.00 & -0.00 & -0.00 & $4.14 \mathrm{E}+09$ & 0.00 & -0.00 & -0.00 & 0.00 \\
\hline
\end{tabular}




\section{Continued}

\begin{tabular}{|c|c|c|c|c|c|c|c|c|c|}
\hline KEN & -0.07 & 0.00 & -0.00 & 0.00 & $4.14 \mathrm{E}+09$ & 0.00 & -0.00 & 0.00 & -0.00 \\
\hline MAR & -0.05 & -0.01 & 0.00 & -0.00 & $4.14 \mathrm{E}+09$ & -0.00 & 0.01 & -0.00 & 0.00 \\
\hline MLI & 72.32 & 9.08 & -8.32 & 8.81 & $7.14 \mathrm{E}+09$ & 0.25 & -8.32 & 10.35 & -8.81 \\
\hline NER & 4.13 & 3.02 & -2.93 & -0.79 & $4.31 \mathrm{E}+09$ & 3.84 & -2.93 & -0.92 & 0.79 \\
\hline NGA & 8.52 & 0.79 & -0.76 & 0.31 & $4.49 \mathrm{E}+09$ & 0.46 & -0.76 & 0.36 & -0.31 \\
\hline NLD & -0.01 & -0.00 & 0.00 & -0.00 & $4.14 \mathrm{E}+09$ & -0.00 & 0.00 & -0.00 & 0.00 \\
\hline PRT & -0.01 & -0.00 & 0.00 & -0.00 & $4.14 \mathrm{E}+09$ & 0.00 & 0.00 & -0.01 & 0.01 \\
\hline SEN & 13.79 & 0.18 & -0.18 & -1.31 & $4.70 \mathrm{E}+09$ & 1.52 & -0.183 & -1.53 & 1.32 \\
\hline SGP & -0.00 & 0.00 & -0.00 & -0.00 & $4.14 \mathrm{E}+09$ & 0.00 & -0.00 & -0.00 & 0.00 \\
\hline SWE & -0.00 & 0.00 & -0.00 & -0.00 & $4.14 \mathrm{E}+09$ & 0.00 & -0.00 & -0.00 & 0.00 \\
\hline TGO & 132.74 & 2.74 & -2.66 & 2.71 & $9.58 \mathrm{E}+09$ & 0.02 & -2.66 & 3.17 & -2.71 \\
\hline THA & -0.01 & 0.00 & 0.00 & -0.00 & $4.14 \mathrm{E}+09$ & 0.00 & -0.00 & 0.00 & -0.00 \\
\hline TUN & -0.03 & -0.00 & 0.01 & -0.00 & $4.14 \mathrm{E}+09$ & -0.00 & 0.00 & -0.01 & 0.01 \\
\hline TUR & -0.00 & -0.00 & 0.00 & -0.00 & $4.14 \mathrm{E}+09$ & 0.00 & 0.00 & -0.00 & 0.00 \\
\hline TZA & -0.01 & 0.00 & -0.00 & -0.00 & $4.14 \mathrm{E}+09$ & 0.00 & 0.00 & -0.00 & 0.00 \\
\hline USA & -0.01 & 0.00 & -0.00 & -0.00 & $4.14 \mathrm{E}+09$ & 0.00 & -0.00 & -0.00 & 0.00 \\
\hline ZAF & -0.05 & 0 & 0 & 0 & $4.14 \mathrm{E}+09$ & 0.00 & 0 & 0 & 0 \\
\hline ZWE & -0.00 & 0.00 & -0.00 & -0.00 & $4.14 \mathrm{E}+09$ & 0.00 & -0.00 & -0.00 & 0.00 \\
\hline
\end{tabular}


Table 4. Countries sample.

\begin{tabular}{|c|c|c|}
\hline Country & Country & Country \\
\hline Algeria & France & Singapore \\
\hline Argentina & Gabon & South Africa \\
\hline Australia & Ghana & Spain \\
\hline Austria & Germany & Sweden \\
\hline Benin & India & Switzerland \\
\hline Bolivia & Indonesia & Tanzania \\
\hline Burkina-Faso & Italy & Thailand \\
\hline Brazil & Japan & Togo \\
\hline Cameroon & Kenya & Tunisia \\
\hline Canada & Mali & Turkey \\
\hline China & Morocco & United Kingdom \\
\hline Colombia & Netherlands & United States of America \\
\hline Côte d'Ivoire & Niger & Zimbabwe \\
\hline Denmark & Nigeria & \\
\hline Egypt & Portugal & \\
\hline Finland & Senegal & \\
\hline
\end{tabular}

